\title{
KONTROVERSI SOSIAL CALEG PEREMPUAN PKS (KOMUNIKASI POLITIK, DOGMA AGAMA \& AFIRMASI)
}

\author{
Agus Machfud Fauzi, Fadilah Salsa Novinayah, Oktavia Ayu Darmawan, Rivaldi \\ Jurusan Ilmu Sosial; Fakultas Ilmu Sosial dan Hukum; Universitas Negeri Surabaya \\ Email: agusmfauzi@unesa.ac.id
}

\begin{abstract}
This study aims to explain the implementation of government policies related to a $30 \%$ quota for women in the East Java PKS DPW, in addition to knowing its implementation. The social controversy responding to the PKS policy in presenting female legislative candidates aims to show to the public that there is a conflict between government policy and Islamic dogma which is the principle in the PKS. This study used qualitative research methods. The results showed that the implementation of government policies related to the 30\% quota for women in the PKS East Java DPW had exceeded those specified, which was at 46\%, whereas according to their interpretation that the prevailing religious dogma had no conflict between prevailing teachings with the government's policy of 30\% of women's quota, all of them have their share in life. AlQuran Surah An-Nisa verse 34 and Surah Al-Ahzab verse 33 textually prohibit women from becoming leaders, this is a source of religious dogma. Social controversy about women becoming leaders is eliminated when they have competence and capacity because the existence of leaders here is not in the context of congregational prayer but rather in carrying out state and national work programs.
\end{abstract}

Keyword: DPW PKS, Religious Dogma, 30\% Quota, Political Communication

\begin{abstract}
Abstrak
Penelitian ini bertujuan untuk menjelaskan implementasi kebijakan pemerintah terkait kuota $30 \%$ bagi perempuan di dalam DPW PKS Jawa Timur, selain untuk mengetahui implementasinya. Kontroversi sosial merespon kebijakan PKS dalam menghadirkan calon legislatif perempuan bertujuan untuk memperlihatkan ke kalayak publik adakah pertentangan antara kebijakan pemerintah dengan dogma agama Islam yang menjadi asas dalam PKS. Penelitian ini menggunakan metode penelitian kualitatif. Hasil penelitian menunjukkan bahwa implementasi kebijakan pemerintah terkait kuota 30\% bagi perempuan di DPW PKS Jawa Timur sendiri sudah melebihi dari yang ditentukan, yaitu berada pada angka $46 \%$, sedangkan menurut tafsir mereka bahwa dogma agama yang berlaku tidak ada pertentangan yang terjadi antara ajaran yang berlaku dengan kebijakan pemerintah tentang 30\% kuota perempuan, semua memiliki porsinya masingmasing di dalam kehidupan. Al-Quran Surat An-Nisa ayat 34 dan Surat Al-Ahzab ayat 33 secara tekstual melarang perempuan menjadi pemimpin, hal ini yang menjadi sumber dogma agama. Kontroversi sosial tentang perempuan menjadi pemimpin tereliminir ketika mereka mempunyai kompetensi dan kapasitas sebab eksistensi pemimpin disini bukan dalam konteks sholat jamaah tetapi lebih kepada menjalankan program kerja bernegara dan berbangsa.
\end{abstract}

Kata Kunci: DPW PKS, Dogma Agama, Kuota 30\%, Komunikasi politik 


\section{Pendahuluan}

Indonesia sebagai negara yang memiliki berbagai macam partai politik (multipartai) perkembangannya penuh dinamis. Ia ada bukan karena reformasi, tetapi dikarenakan adanya sistem multipartai yang dijalankan Indonesia semenjak teraihnya kemerdekaan sebagaimana yang tertulis dalam Surat Keputusan Wakil Presiden M. Hatta No. $\mathrm{X} / 1945$, selanjutnya menjadi tonggak dilaksanakannya sistem multipartai dalam dunia perpolitikan Indonesia (Ristyawati, 2016: 3). Preferensi politik didefinisikan lebih dari ruang kebijakan multidimensi. ( Glacer, 1999: 391)

Kontroversi sosial yang dibungkus dinamika politik di Indonesia seiring sejalan dengan dinamika perilaku pemilihnya.(Fauzi, 2018: 40) Ia berkembang dengan berbagai kebijakan yang berubah pada setiap menyongsong pesta demokrasi dilaksanakan. Ia tidak dapat terlepas dari sistem multipartai, hal ini dikarenakan tingginya pluralitas dari segi ideologi dan budaya. Sistem multipartai ini sebagai penyebab perkembangan jumlah partai politik seperti semenjak tahun 1999 melonjak menjadi 48 partai politik yang kemudian baru mengalami penurunan ketika memasuki tahun 2009 menjadi 38 partai politik dan pada tahun 2014 akhirnya menjadi hanya 14 partai politik (BPS, 2016: 3). Pada tahun 2019 berubah menjadi 16 partai politik nasional. Komunikasi politik berperan besar terhadap dinamika perpolitikan yang berkembang di tengah masyarakat yang mencari bentuk demokrasi. Setiap partai dapat menurunkan satu kandidat per konstituensi, dan berbagai kandidat independen (tidak selaras dengan partai mana pun) juga ikut serta dalam pemilihan. Calon dapat mencalonkan diri untuk pemilihan, dan menang. (Afzal, 2013: 56).

Kebijakan negara berefek pada keterlibatan perempuan dalam dunia politik. Penambahan kebijakan mengenai kuota keterwakilan perempuan yang harus sampai pada proporsi $30 \%$ yang berlaku mulai pada Pemilu tahun 2009, perempuan dalam daftar calon tetap (DCT) minimal terdapat satu orang perempuan dari tiga orang yang akan dicalonkan (BPS, 2016: 4). Begitupula dalam UU Partai Politik No. 2 Tahun 2011 yang menyebutkan pengurus partai politik sekurang-kurangnya menyertakan perempuan sekurang-kurangnya $30 \%$ dan pada UU No. 8 Tahun 2012 tentang Pemilu Legislatif DPR, DPRD dan DPD, menyebutkan dalam rekruitmen caleg 
$30 \%$ adalah caleg perempuan. Hal tersebut juga hadir kembali pada UU No 7 tahun 2017 sebagai regulasi pada pemilu 2019. Keterwakilan perempuan dalam politik tidak saja didasarkan pada keikutsertaannya dalam pengambilan keputusan, lebih pentinga lagi kontribusinya demi memperjuangkan hakhak kaum perempuan. (Djou, 2018: 605)

Kebijakan ini merupakan suatu kebijakan yang saat ini ramai diperbincangkan, yaitu kewajiban bagi partai politik dalam memberikan keterwakilan perempuan dengan kuota $30 \%$. Hal ini dapat dikatakan sebagai bentuk perwujudan usaha dalam menyukseskan kesetaraan gender yang ada di Indonesia. Salah satu penelitian dari Nelli menyebutkan bahwasanya keterlibatan perempuan dalam dunia perpolitikan merupakan suatu yang penting, karena perempuan dianggap memiliki kebutuhan-kebutuhan khusus yang hanya dapat dipahami oleh perempuan sendiri (Nelli, 2015: 255). Hal tersebut menjelaskan betapa pentingnya kebijakan ini, dimana tidak hanya memberikan kursi untuk perempuan masuk ke dunia perpolitikan, tetapi juga untuk memperjuangkan kebutuhan- kebutuhan khusus yang dimiliki perempuan agar lebih didengar dalam pemerintahan yang ada. Kebijakan keterwakilan legislatif perempuan tersebut, dalam implementasinya baru pada tahap kandidasi dan belum sampai tahap bagaimana bisa terpilih, sehingga sebatas menggugurkan kwajiabn bahwa jumlah calon $30 \%$ keterwakilan perempuan selalu dapat dipenuhi parpol sebagai syarat mengikuti kontestasi pemilu. (Murdyastuti, 2016: 67)

Namun dalam pelaksanaannya kebijakan ini masih mengalami pro dan kontra. Dimana terdapat beberapa partai politik yang telah menjalankan kebijakan ini, namun disisi lain juga terdapat beberapa partai politik yang masih belum bisa mengisi porsi $30 \%$ ini seperti yang dijelaskan dalam salah satu penelitian terdahulu yang berjudul "Politik Hukum Keterwakilan Perempuan di Lembaga Legislatif Era Reformasi" menyebutkan bahwasanya masih terdapat beberapa partai politik yang belum bisa memenuhi kuota keterwakilan perempuan 30\% yaitu pada Partai Peduli Rakyat Nasional (PPRN), Partai Gerakan Indonesia Raya (Gerindra), Partai Persatuan Pembangunan dan Partai Patriot (Utami, 
2016: 143). Ketidak mampuan diantaranya pola komunikasi vertikal pemenuhan tersebut karena tidak bisa melaksanakan komunikasi politik dengan kaum perempuan. Komunikasi politik merupakan suatu kemestian bagi dalam proses politik antara partai politik dengan kandidat politik perempuan yang mencalonkan diri sebagai calon anggota parlemen. (Dwirainaningsih, 2018: 766)

Berbagai permasalahan muncul di kedua sisi. Di satu sisi, bagi partai politik yang sudah memenuhi kuota $30 \%$ perempuan, masih dianggap 30\% tersebut hanya digunakan untuk pengisi saja bukan semata-mata orang yang berkompeten di dalam bidangnya, seperti penelitian Utami yang juga menjelaskan tentang perekrutan kader baru yang kurang selektif dengan alasan minimnya waktu yang dibutuhkan menjadikan terbentuknya kader ala kadarnya, tanpa melihat latar belakang serta pengalaman yang dimilikinya dalam organisasi politik (Utami, 2016: 134). Disisi lain juga yaitu partai-partai yang masih belum bisa memenuhi kuota tersebut juga merupakan sebuah masalah, dimana dalam hal ini berarti pemerintah belum dapat sepenuhnya menjalankan kebijakan yang telah ditetapkan ini. Komunikasi politik memiliki pola-pola, sebagaimana yang sering berjalan dari atasan ke bawahan dan sebaliknya, pola komunikasi horizontal yang terjadi antara masyarakat sendiri, pola komunikasi formal dengan jalur organisasi formal, dan pola komunikasi informal dengan pertemuan tidak mengikuti prosedur sebagaimana yang berlaku formal dalam organisasi. (Sartika, 2016: 138)

Regulasi negara dibuat sewajarnya seiring sejalan dengan kebijakan partai politik dalam menghadirkan afirmasi $30 \%$ kuota perempuan. Sangat tidak bijaksana seandainya kebijakan tersebut bertentangan dengan pelaksanaan demokrasi. Misalkan ada suatu kebijakan penyelenggara pemilu tentang kebijakan bahwa semua pemilih wajib hadir di TPS pada saat pemungutan suara, hal ini bertentangan dengan azas-azas demokrasi. (Fauzi, 2018: 314)

Salah satu partai yang telah menerapkan kebijakan kuota 30\% perempuan ialah Partai Keadilan Sejahtera atau yang biasa disebut PKS. PKS merupakan suatu partai yang berasaskan agama Islam, dimana kebijakan partai juga dibentuk berasaskan ajaran agama Islam tersebut. Di dalam 
ajaran agama Islam sendiri laki-laki dianggap lebih pantas menjadi pemimpin dibandingkan dengan perempuan seperti yang terdapat dalam Al-Quran Surat AnNisa Ayat 34 yang berbunyi "Kaum pria itu adalah pemimpin bagi kaum wanita". Begitupula keberadaan perempuan yang jika sudah menikah sebaiknya hanya berada di rumah saja seperti yang terdapat di dalam Surat Al-Ahzab Ayat 33 yang berbunyi "Hendaklah kalian (para istri) tetap dirumah kalian”. Hal ini menjelaskan bahwasanya perempuan dalam ajaran agama Islam sendiri memiliki beberapa tantangan jika ingin berkarir di luar rumah terutama bagi perempuan yang telah berkeluarga. Pernyataan seperti ini tentunya dapat terlihat sangat bertentangan antara kebijakan pemerintah terkait kuota 30\% bagi perempuan dengan ajaran (dogma) agama Islam terkait perempuan yang secara langsung maupun tidak langsung diyakini oleh Partai PKS yang notabene merupakan partai berbasis Islam. Akan tetapi, di satu sisi partai ini juga berhasil mengisi kuota $30 \%$ bagi perempuan.

\section{METODOLOGI PENELITIAN}

Penelitian ini menggunakan metode penelitian kualitatif. Penelitian kualitatif sangat relevan memahami fenomena apa yang dipahami oleh subjek penelitian misalnya perilaku, persepsi, motivasi, tindakan dan lain lain, secara holistik dan deskriptif. Penelitian kualitatif dipilih karena metode kualitatif dapat memberikan detail data yang lebih kompleks tentang fenomena yang sulit diungkapkan oleh metode kuantitatif. Proses penelitian kualitatif, supaya dapat menghasilkan temuan yang benar-benar bermanfaat, memerlukan perhatian yang serius terhadap berbagai hal yang dipandang perlu. Penelitian ini dilakukan di DPW PKS Jawa Timur. Lokasi penelitian dipilih dengan alasan metodologis sesuai dengan tema yang akan dibahas dalam penelitian ini. Dimana Partai PKS sendiri merupakan partai berbasis agama Islam yang juga harus mengikuti peraturan kuota 30\% bagi perempuan yang dikeluarkan oleh pemerintah. Waktu penelitian dilakukan selama 1 bulan setelah menentukan judul dan membuat serangkaian pertanyaan. Dalam proses wawancaranya dilakukan secara bersama kelompok dan disesuaikan dengan waktu subyek penelitian yang sedang sibuk karena sedang melakukan sosialisasi terkait urusan beliau menjadi 
caleg. Subyek merupakan Kepala Bidang Perempuan dan Ketahanan Keluarga DPW PKS Jawa Timur. Teknik wawancara yang digunakan adalah indepth interview. Hasil wawancara ditulis langsung oleh peneliti dalam buku catatan dan juga direkam dengan perekam suara di handphone. Dalam penelitian ini menggunakan panduan wawancara agar mendapatkan data yang mendalam.

\section{HASIL DAN PEMBAHASAN}

Temuan data yang didapatkan berdasarkan wawancara dengan Ibu $\mathrm{X}$ (Informan) selaku Ketua Bidang Perempuan dan Ketahanan Keluarga DPW PKS Jawa Timur adalah bahwa memang benar PKS merupakan partai yang berasaskan Islam. Akan tetapi, PKS juga menjalankan dan memberikan hak $30 \%$ keterwakilan perempuan di dalam partai PKS itu sendiri. Terlebih, pemberian hak kuota $30 \%$ bagi perempuan tidak hanya semata-mata untuk menjalankan peraturan pemerintah, melainkan perempuan yang sudah masuk dan terpilih telah memiliki potensi yang baik dan mampu dalam pekerjaannya serta telah memiliki kapasitas dan kemampuan. Komunikasi politik dibangun secara vertikal antara pengurus dan kader, begitu juga dilaksanakan secara horizontal yaitu sesame kader PKS untuk membangun partai dalam merespon tantangan pesta demokrasi 2019.

Dalam PKS dipahami bahwa tugastugas partai politik lebih banyak diberikan pada laki-laki sebagaimana produk komunikasi informal partai politik, namun ada juga pekerjaan yang memang harus dikerjakan oleh perempuan. Dalam urusan dukungan pekerjaan, perempuan pun juga sangat terbantu oleh adanya laki-laki karena dorongan dan semangat juga diberikan kepada para perempuan di dalam partai tersebut. Dukungan dalam keluarga pun sangat bagus karena keluarga mendukung keputusan Ibu X untuk menjadi caleg.

Komunikasi politik vertikal dan formal PKS terhadap para kadernya dengan untuk menguatkan partai politiknya, maka menampilkan 8 program kerja yang dilakukan oleh Ibu X selaku Ketua Bidang Perempuan dan Ketahanan Keluarga yaitu: (1) Pendidikan pranikah; (2) Pendidikan Parenting; (3) Konseling bagi keluarga yang bermasalah; (4) Pendidikan bagi Lansia; (5) Pendidikan bagi ibu dan remaja. Pendidikan diberikan 
dengan membuat sekolah untuk ibu-ibu dengan nama Rumah Pelangi yang agendanya seperti memberi les terkait keterampilan khusus seperti menjahit; (6) Pendidikan politik, yang digunakan untuk memberikan pengetahuan umum terkait dunia perpolitikan dan berupaya menghapuskan pandangan bahwa politik itu kotor. Maksud dari program kerja ini adalah untuk mengedukasi banyak masyarakat yang masih rendah akan pengetahuan politiknya sehingga memilih untuk golput. Sehingga program ini memberikan pengetahuan tentang berpolitik guna mengurangi angka golput. PKS mempunyai kesadaran bahwa angka golput tinggi (kira-kira golput kurang lebih 40-50\%), sehingga berkepentingan untuk meraih pemilih yang golput tersebut.

Ibu X menyampaikan bahwa terdapat aktor-aktor politik yang melakukan tindakan korupsi sehingga membuat pandangan bahwa politik itu kotor, akan tetapi juga ada aktor-aktor politik yang melakukan tugasnya dengan amanah, namun media seringkali memperlihatkan bagian sisi buruk politik dibanding dengan sisi baiknya. Karena sisi baik dari politisi itu memang sudah merupakan kewajiban dari mereka sehingga tidak perlu di beritakan kembali. Maka pendidikan politik itu penting dan masyarakat diharapkan dapat mengenal siapa yang akan dipilihnya nanti, karena siapa yang akan terpilih nanti akan menentukan jalannya pemerintahan ini akan dibawa kemana; (7) Membangun RKI (Rumah Keluarga Indonesia) yang berperan memberikan bimbingan, konsultasi keluarga, pendidikan politik kepada kaum perempuan dan kegiatan pemberdayaan terhadap perempuan baik berupa pelatihan keterampilan maupun penguatan pemahaman keagamaan; dan (8) Mengadakan kajian dengan Focus Group Discussion (FGD) mengenai peran perempuan dan ketahanan keluarga. Delapan program kerja tersebut memang mengatasnamakan partai namun bukan semata-mata untuk mencari suara tetapi hal ini memang ditujukan untuk masyarakat. Karena asas yang dimiliki oleh partai PKS ini ialah melakukan proyek secara ikhlas untuk pembangunan masyarakat dan masalah suara itu adalah bonus.

Pada Bidang Perempuan dan Ketahanan Keluarga DPW PKS Jawa Timur sendiri, terdapat 4 (empat) deputi, 
yaitu Deputi Ketahanan Keluarga dan Anak, Deputi Hubungan Kemasyarakatan, Deputi Peningkatan Kapasitas Kader Perempuan dan Deputi Kajian Perempuan dan Anak. Jumlah kader yang ada di DPW PKS Jawa Timur sendiri masih banyak laki-laki dibandingkan perempuan tetapi dalam hal jumlah perempuan tiap tahunnya mengalami peningkatan. Ilmu dan akhlaq merupakan pedoman bagi PKS. Di Bidang Perempuan dan Ketahanan Keluarga ini keseluruhannya dianggotai oleh perempuan karena di anggap lebih mengerti dan menguasai bidang ini. Akan tetapi informan mengatakan seharusnya ada juga anggota laki-laki yang diharapkan dapat masuk di bidang ini dan membantu konseling yang dilakukan untuk pasangan suami-istri yang bermasalah, yang merupakan program kerja dari Deputi Ketahanan Keluarga dan Anak.

\section{Implementasi Kebijakan $30 \%$ Kuota} Perempuan di DPW PKS Jawa Timur

Implementasi dari kebijakan ini terlihat dari pemilihan Kepala Bidang di DPW PKS Jawa Timur dimana untuk pemilihan Kepala dari 14 bidang yang ada di PKS dilakukan pemilihan umum raya atau pemira yang di dalamnya terdapat kader-kader potensial pilihan Ketua Umum. Sementara itu untuk Ketua Deputi dipilih oleh Ketua Bidang masing-masing. Pemilihan kader-kader untuk ketua ini sepenuhnya berdasarkan kompetensi dari kader tersebut dan tidak membedabedakan atas perbedaan gender.

Untuk pengisian kuota 30\% keterwakilan perempuan, pemberlakuannya bukan hanya terdapat pada struktur organisasi partai politik tetapi juga pada proses perkaderan, dimana setiap Daerah Pilih atau Dapil diwajibkan untuk memberikan keterwakilan perempuan sebesar 30\% juga. Penentuan nomer urut pilih juga berdasarkan kapasitas dan kompetensi dari kader yang dicalonkan. Jadi tidak menutup kemungkinan kalau perempuan bisa mendapatkan nomor urut pilih 1. Menurut informan, pada kesempatan kali ini justru yang menjadi caleg dari DPW PKS Jawa Timur Dapil 1 itu mayoritas perempuan dengan jumlah 3 perempuan. Informan menjadi Caleg Dapil 1 nomor urut 2.

Kebijakan PKS khususnya pada Provinsi Jawa Timur kebijakan pemerintah tentang keterwakilan perempuan sebanyak $30 \%$ telah di 
lakukan, bahkan PKS telah melebihi dari kebijakan pemerintah dimana indeks keterwakilan perempuan sudah sampai sekitar 46\%. Mirisnya di partai-partai lain masih banyak yang belum bisa memenuhi kuota $30 \%$ tersebut dan berusaha memenuhi kuota tersebut dengan membuka Open Recruitmen Caleg pada banner yang terpasang dijalan. Bukan hanya itu mereka juga mencoba merekrut para artis untuk menjadi Calon Legislatif yang belum tentu mereka memiliki kapasitas untuk mencalonkan diri.

\section{Dogma Agama dalam DPW PKS Jawa} Timur

Agama dan politik seringkali dianggap sebagai sesuatu yang tidak dapat digabungkan, hal ini selanjutnya menghadirkan kontroversi sosial. Namun dalam PKS bahwa anggapan tersebut dapat dikesampingkan, karena menurut informan partai ini memiliki asas yaitu melaksanakan proyek secara ikhlas dan urusan mendapatkan suara adalah bonus. Jadi istilah perpolitikan merupakan suatu yang kotor dan tidak pantas bagi orang yang beragama khususnya beragama Islam dapat dihilangkan.
Seperti yang telah dijelaskan sebelumnya, dalam ajaran agama Islam, laki-laki memegang peranan sebagai pemimpin dan perempuan adalah yang dipimpin. Terlebih ketika perempuan tersebut sudah berkeluarga, maka lebih baik ia berada dirumah dan mengurus anak-anak serta pekerjaan domestik lainnya. Lalu, apakah dogma ini berlaku di PKS yang notabene merupakan partai berbasis Islam? Menurut informan, dirinya selama menjadi Kepala Bidang Perempuan dan Ketahanan Keluarga di DPW PKS Jawa Timur ini tidak merasa akan adanya perbedaan sikap dan pola resistensi dari rekan-rekan kerjanya yang laki-laki. Hal ini dikarenakan mereka semua yang berada di partai politik tersebut sudah tahu bahwa perkara menjadi pemimpin atau tidaknya itu berdasarkan kompetensi dan kemampuan. Contohnya pada Bidang Ekintek yang diketuai oleh Ibu Reni yang notabenenya adalah perempuan akan tetapi memiliki kemampuan yang lebih mumpuni daripada laki-laki, maka dirinya terpilih menjadi pemimpin di Bidang Ekintek itu. Tentu jika perempuan yang menjadi pemimpin tidak masalah, karena pemimpin disini bukan dalam konteks 
sholat jamaah tetapi lebih kepada menjalankan program kerja yang telah di susun. Walaupun memang dalam 14 (empat belas) bidang yang ada di DPW PKS Jawa Timur hanya terdapat dua perempuan yang menjadi Kepala Bidang.

Pernyataan ini seolah-olah untuk mengklarifikasi bahwa persepsi masyarakat terkait dogma agama Islam yang sangat kental berada di tubuh Partai PKS merupakan hal yang keliru. Walaupun informan mengakui bahwa memang ada hal-hal yang tugasnya tidak dapat dipertukarkan antara laki-laki dan perempuan. Akan tetapi dalam urusan pekerjaan, semuanya tidak dapat dilihat pada satu sisi agama saja, karena memang kemampuan tiap orang berbeda-beda, meskipun informan juga mengakui bahwa terkadang fisik perempuan kalah dibanding fisik laki-laki.

Pada PKS Provinsi Jawa Timur kebijakan pemerintah tentang keterwakilan perempuan sebanyak 30\% telah di lakukan, bahkan PKS telah melebihi dari kebijakan pemerintah dimana indeks keterwakilan perempuan sudah sampai sekitar 46\%. Mirisnya di partai-partai lain masih banyak yang belum bisa memenuhi kuota $30 \%$ tersebut dan berusaha memenuhi kuota tersebut dengan membuka Open Recruitmen Caleg pada banner yang terpasang dijalan. Bukan hanya itu mereka juga mencoba merekrut para artis untuk menjadi Calon Legislatif yang belum tentu mereka memiliki kapasitas untuk mencalonkan diri. Untuk pengisian kuota 30\% keterwakilan perempuan, pemberlakuannya bukan hanya terdapat pada struktur organisasi partai politik tetapi juga pada proses perkaderan, dimana setiap Daerah Pilih atau Dapil diwajibkan untuk memberikan keterwakilan perempuan sebesar 30\% juga. Penentuan nomer urut pilih juga berdasarkan kapasitas dan kompetensi dari kader yang dicalonkan. Jadi tidak menutup kemungkinan kalau perempuan bisa mendapatkan nomor urut pilih 1.

Informan Kepala Bidang Perempuan dan Ketahanan Keluarga di DPW PKS Jawa Timur tidak merasa akan adanya perbedaan sikap dan pola resistensi dari rekan-rekan kerjanya yang laki-laki. Hal ini dikarenakan mereka semua yang berada di partai politik tersebut sudah tahu bahwa perkara menjadi pemimpin atau tidaknya itu berdasarkan kompetensi dan kemampuan. Tentu jika perempuan 
yang menjadi pemimpin tidak masalah, karena pemimpin disini bukan dalam konteks sholat jamaah tetapi lebih kepada menjalankan program kerja yang telah di susun. Walaupun memang dalam 14 bidang yang ada di DPW PKS Jawa Timur hanya terdapat 2 perempuan yang menjadi Kepala Bidang.

Pernyataan ini seolah-olah untuk mengklarifikasi bahwa persepsi masyarakat terkait dogma agama Islam yang sangat kental berada di tubuh Partai PKS merupakan hal yang keliru. Walaupun informan mengakui bahwa memang ada hal-hal yang tugasnya tidak dapat dipertukarkan antara laki-laki dan perempuan. Akan tetapi dalam urusan pekerjaan, semuanya tidak dapat dilihat pada satu sisi agama saja, karena memang kemampuan tiap orang berbeda-beda, meskipun informan juga mengakui bahwa terkadang fisik perempuan kalah dibanding fisik laki-laki.

\section{KESIMPULAN}

PKS sebagai partai politik mempunyai kebijakan tersendiri dalam menempatkan para kadernya untuk menjadi calon pemimpin bangsa, termasuk para kader perempuannya. PKS tidak melihat negatif terhadap kader perempuan. Dogma agama tentang kepemimpinan tidak dipahami secara tekstual sehingga berbeda dengan pandangan orang selama ini terhadap partai politik dakwah ini. Pandangan terhadap kontroversi sosial menjadi tidak ada.

$30 \%$ kuota perempuan dipenuhi sesuai dengan regulasi Negara, bahkan pada pemilu 2019 bahwa PKS Jawa Timur menampilkan kadernya melebihi kuantitas minimal yang dipersyaratkan oleh UU No 7 tahun 2017.

Komunikasi politik menjadi kata penghubung partai politik dengan para kadernya sehingga mampu menampilkan para kadernya bersedia menjadi calon anggota legislatif. Terpilih atau tidak terpilih, bukan sesuatu yang menghalangi para kader PKS tampil menjadi calon legislator.

\section{DAFTAR PUSTAKA}

Afzal, Madiha. 2014. "Do barriers to candidacy reduce political competition? Evidence from a bachelor's degree requirement for legislators in Pakistan”. Public Choice 161 (51-72). 
BPS. 2016. Statistik Politik 2016. Badan

Pusat Statistik.

Djou, Ana Maria Gadi \& Liza Quintarti. 2018. "Partisipasi Perempuan dalam Partai Politik dan Pemilu Serentak”. Jurnal Unnes Vol. 4 No. 3 Tahun 2018.

Dwirainaningsih, Yustiana. 2018. "Komunikasi Politik Calon Anggota Legislatif Pemilu (Analisis Affirmative Action) Kuota 20 Persen Keterwakilan Perempuan di Legislatif pada Daeah Pemilihan Kota Pekalongan”. Jurnal UNNES Volume 4 Nomor 3 (761-776).

Fauzi, Agus Machfud. 2018. Perilaku Pemilih Menjelang Pemilu 2019. Jurnal of Islamic Civilization Vol.1 No.13 (40-49).

Fauzi, Agus Machfud, Arief Affandi \& Oksiana Jatisingsih. 2018. Voter Participation Target Vs Democracy, Election Organizer Program on the Use of Voting Right in East Java 2018. $1^{\text {st }}$ International Conference on Social Sciences (ICSS 2018) (311315)
Glazer, Amihai \& Susanner Lohmann. 1999. "Setting the agenda: Electoral competition, commitment of policy, and issue salience". Kluwer Academic Publishers. Printed in the Netherlands

Murdyastuti. 2016. "Peningkatan Kesetaraan Gender Terhadap Keterwakilan Perempuan Dalam Kegiatan Politik di Lembaga Legislatif Kabupaten Banyuwangi”. Lentera, Jurnal Studi Perempuan Vol.12 No. 1 Tahun.

Nelli, Jumni. 2015. Eksistensi Perempuan pada Lembaga Politik Formal dalam Mewujudkan Kesetaraan Gender. Jurnal Mawah.

Ristyawati, $\quad$ Aprista. 2016. Penyederhanaan Partai Politik dalam Sistem Kepartaian di Indonesia Sejak Perubahan Undang-Undang 1945. EJournal Universitas Diponegoro.

Simatupang, Jonasmer dan Muhammad Subekhan. 2018. "Pengaruh Budaya Politik Uang dalam Pemilu terhadap Keberlanjutan Demokrasi Indonesia. Fakultas Hukum Universitas Negeri Semarang”. Jurnal Unnes Vol. 4 No. 3 Tahun 2018. 
.Sartika, Diana Dewi, Eva Lidya \& Tri Utami, Nofi Sri. 2016. Politik Hukum

Agus Susanto. 2016. "Komunikasi Politik Caleg Perempuan Untuk Pemilihan Anggota Legislatif Kota Palembang”. Jurnal Sosiologi USK Volume 10 Nomor 2 (135-155).
Keterwakilan Perempuan di Lembaga Legislatif Era Reformasi. Seminar Nasional Hukum Universitas Negeri Semarang.Moonti, Roy Marthen dan Marten Bunga. 2018. "Dampak Politik Uang Terhadap Demokrasi”. Fakultas Hukum Universitas Gorontalo: Jurnal Unnes Vol.4 No. 3 Tahun 2018. 